\title{
Drastic impacts of COVID-19 on food, agriculture and economy
}

\author{
Nawab Khan ${ }^{1}$, Badar Naseem Siddiqui², Nanak Khan ${ }^{3}$, Naqeeb Ullah ${ }^{4}$, \\ Akhtar Wali ${ }^{5}$, Imad Uddin Khan ${ }^{6}$, Sohaib Ismail ${ }^{7}$ and Muhammad \\ Ihtisham $^{8 *}$ \\ 1. College of Management, Sichuan Agricultural University Chengdu Campus, Wenjiang 611100, Sichuan-China \\ 2. Department of Agricultural Extension, PMAS-Arid Agriculture University Rawalpindi-Pakistan \\ 3. of Agronomy, Balochistan Agriculture College, Quetta-Pakistan \\ 4. Directorate of Post-Harvest and Food Technology Agriculture Research Institute ARI Sariab, Quetta-Pakistan \\ 5. Doctor of Veterinary Medicine (DVM) PVMC, Pakistan, Faculty of Veterinary Science, University of \\ Agricultural, Faisalabad-Pakistan \\ 6. Department of Economics and Finance, International Islamic University Islamabad-Pakistan \\ 7. Rice Research Institute, Department of Plant Pathology, Sichuan Agricultural University, Chengdu-China \\ 8. Collage of Landscape Architecture, Sichuan Agricultural University Chengdu Campus, Wenjiang 611100, \\ Sichuan-China \\ *Corresponding author's email: ihtisham@ sicau.edu.cn \\ Citation
}

Nawab Khan, Badar Naseem Siddiqui, Nanak Khan, Naqeeb Ullah, Akhtar Wali, Imad Uddin Khan, Sohaib Ismail and Muhammad Ihtisham. Drastic impacts of COVID-19 on food, agriculture and economy. Pure and Applied Biology. Vol. 10, Issue 1, pp62-68. http://dx.doi.org/10.19045/bspab.2021.100008

\begin{tabular}{llll}
\hline \hline Received: 16/05/2020 & Revised: 11/08/2020 & Accepted: 20/08/2020 & Online First: 26/08/2020 \\
\hline \hline
\end{tabular}

\section{Abstract}

Global epidemics and illness outbreaks are the huge threats to human prosperity and sustainability. In mankind history, humans have faced many epidemics that have caused millions of deaths and destroyed the global economy, politics, etc. Under the existing era, the globe is facing another pandemic, namely the Coronavirus Disease-2019 (COVID-19). Aware of the gravity and severity of the prevailing situation, each country has taken special steps to combat this dinger epidemic, mainly through nonpharmaceutical trails including self-isolation and social distance. Moreover, most countries restrict travel and trade to limit the spread of the coronavirus. By adopting these measures, still the epidemic has greatly pretentious key economic sectors, for instance agriculture, the most significant economic sector that supports human development and food security. The review aims to explore possible drastic impacts of worldwide pandemic (COVID-19) on food and agriculture sector. It is very significant to assess the impact of COVID-19 epidemic on the food, agriculture, and economy, because it mainly concerns the sustainability of human existence and the economy. The guidelines and regulations to curb pandemic interfered with the markets supply chain, resulting halt production, distribution, and lack of labor and inputs. This has greatly affected dairy production, poultry, livestock and fisheries. During the pandemic, it was not possible to plant spring crops, such as, open field of vegetables, wheat, maize, barley, sunflower, and canola. Therefore, due to the supply chain, the pandemic has serious impacts on food, agriculture, and economy, which the governments need to quickly resolve this issue.

Keywords: Agriculture; COVID-19; Epidemics; Economy; Food security; Food safety

\section{Introduction}

The global pandemic is not a novel burning issue for mankind because there are numerous spells of several infections (Table 1). Human happenings and economic progress have been affected by every epidemic all over the creature [1]. We are now facing the coronavirus in 2019-20. All-inclusive COVID-19 is an illness spread through acute respiratory syndrome 2 (SARS-COV-2) [2]. The first case of CAVID-19 was detected by a virus outbreak centered in Wuhan (the capital city of Hubei Province, China). Due to the 
discovery of the virus strain, the disease spreads at an alarming rate from person to person. On March 11, 2020, the World Health Organization (WHO) declared COVID-19 a global epidemic [3]. Many people in the world are infected with the deadly virus (Fig. 1). COVID-19 is believed to have a greater impact on the global economy, then severe acute respiratory syndrome (SARS). The
Organization for Economic Cooperation and Development (OCED) predicts that economic growth will decline from $2.9 \%$ to $2.4 \%$ by 2020 , and that if the epidemic continues, economic growth will reach almost $1.5 \%$ [4]. The International Labor Organization (ILO) pointed out that "the COVID-19 is very serious crisis since World War II" [5].

Table 1. The Main Pandemics in the 20th Century

\begin{tabular}{|c|c|c|c|c|}
\hline Pandemics & Period & Causative Agent & Death Toll & Ref. \\
\hline Spanish Flu & $1918-1920$ & H1N1 strain of influenza A virus & About 50 millions & {$[6]$} \\
\hline Asian Flu & $1957-1958$ & H2N2 strain of influenza A virus & 1.1 millions & {$[7]$} \\
\hline Hong Kong Flu & $1968-1970$ & H3N3 strain of influenza A Virus & 1 million & {$[8]$} \\
\hline HIV/AIDS & 1981-present & Human immunodeficiency & $\begin{array}{c}\text { About 32 millions } \\
\text { (end 2018) }\end{array}$ & {$[9]$} \\
\hline COVID-19 & 2019-Present & SARS-CoV-2 & $\begin{array}{c}747,452 \text { August 12, } \\
2020\end{array}$ & {$[10]$} \\
\hline
\end{tabular}

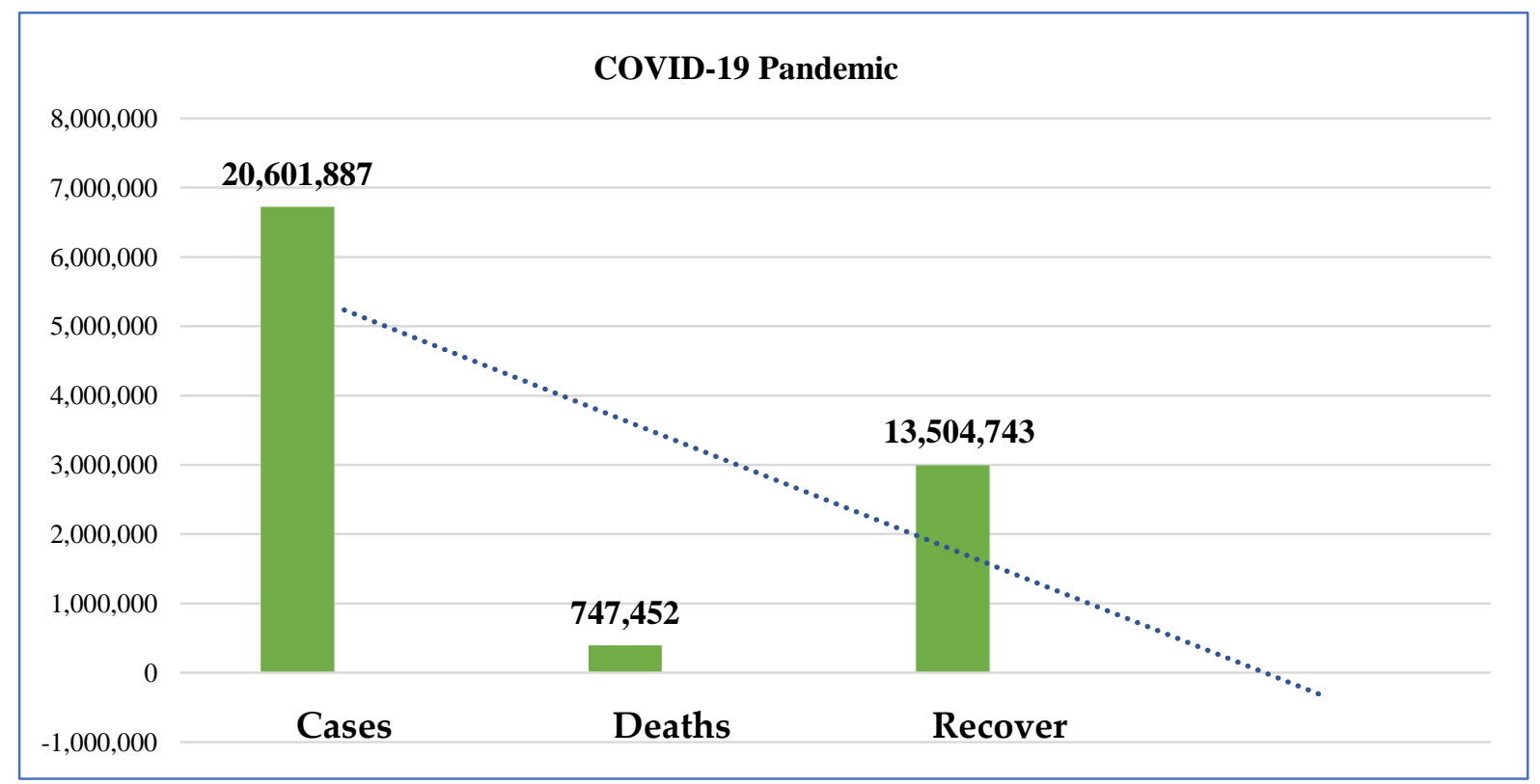

Figure 1. The COVID-19 caused globally deaths and confirmed cases [4]

Agriculture is one of the most significant sectors of the worldwide economy and the largest industry in the United States. Agriculture is essential for human development and food security [10]. Food and Agriculture Organization (FAO) assessed that greater than sixty percent of the worlds' population depends on farming sector for subsistence [11]. Corresponding
ILO data, $26.85 \%$ of the whole number of labor force in 2019 belongs to the agriculture sector $[11,12]$. With the continuing worldwide epidemic of COVID19 , it is extremely critical and important to scrutinize the effect of COVID-19 on agricultural, food and economy. Consequently, this article addresses the possible impacts of Covid-19 on food, 
agriculture, and economy in a worldwide perspective.

\section{COVID-19 and its impacts on food and agriculture}

The COVID-19 disturbs whole activities that link farm production to the final customer. In addition, it looks to have hit food and agriculture production and food value chains system. Drastic impacts of the pandemic on agriculture, food supply, and demand may put food safety at risk [13]. The COVID-19 may harshly disappoint the main food supply chain, including the food chain between urban and rural areas. Restricting movement or importing and exporting may lead to challenges in transporting basic food and entering processing units and markets, thereby affecting producers and consumers. This may result in reduced incomes of farmers, unstable food prices, and deviations from geographical and seasonal patterns, thereby creating uncertainty for producers and consumers. This may have serious adverse effects, especially for the most vulnerable actors, such as informal workers, vulnerable urban populations, displaced persons and others that depend heavily on the market to meet their food requirements. The reduction or reduction of wages, unstable prices, and easy access to basic food will seriously affect the severe food security and malnutrition levels of the people.

COVID-19 and its impacts on food production and distribution

Worldwide, several nations have taken measures for instance, restricting activities at home, business, prohibiting travel, closing universities and school to control the infection rate. This travel constraint disturbs all phases of the food supply chain and has a most critical effect on food supply (Fig. 2). Due to COVID-19, global market trade is believed to have dropped by $13 \%$ to $22 \%$ [12]. The pandemic has dealt a heavy blow to various agricultural sectors such as fisheries, livestock and crops. The COVID19 in China has caused a greater impact on animal husbandry due to restrictions on access to animal feed and labor shortages [14]. Travel prohibitions in several nations have influenced the breeding of poultry. The International Poultry Council (IPC) warns that if travel restrictions are extended, there will be no hatching eggs breeding stocks [13]. Fish is a most important source of energy and protein, accounting for more than seventy percent of the protein of animals for three millions people [13]. Due to sanitation measures, the limited supply of inputs and shortage of labor, fishing activities in different regions of Asia, Africa and Europe have reduced [15]. Fish farmers cannot sell their harvests and it is very challenging to carry out aquaculture due to lack of feed and spawns. Most agricultural products are perishable in nature, so growers have to store unsold agricultural products for long time, which precedes to a decrease in food quality and an increase in production costs [16]. The dairy products and milk supply have been hit hardest by COVID-19. With the decreased supply of milk, the milk processing companies reduced significantly, ultimately, the dairy growers are forced to discard milk and byproducts. Dairy growers in the United State estimate that dairy growers across the country pour nearly 4 million gallons of milk every day [17]. Moreover, dairy products cost two billion Nepalese Rupees have been destroyed and dairy stocks worth five billion Nepalese Rupees appear to be deteriorating in Nepal [13].

Due to turbulent worldwide trade, growers are facing many issues shortages of agricultural inputs such as fertilizers, herbicides, pesticides, and seeds. China is the major fertilizer producer and exporter in the world. The China lockdown has seriously affected the international trade of fertilizers [13]. The pandemic effected the cultivation of spring season crops such as wheat, maize, barley, rape, sunflower, and open field foods/vegetables. According to Singh, only Indian country needs 25 Million hectors of seeds to produce crops in the kahrif season [18]. Thus, if the 
pandemic period is extended the plantation of zaid and kahrif seasons crops may be effected. Therefore, import-dependent nations seem to be severely affected by the pandemic. About the high transmission rate of COCID-19, health workers and shortages of labor have become the major problems in agriculture sector. Workforces in low and middle-level income countries require adequate facilities of health and community security. Because of a small amount or no savings, despite the selfisolation measures taken during the COCID-19 pandemic, many informal farming workforces are still obligated to work. Thus, these workforces confront a high risk of contracting coronavirus. Almost all farm producers are tackling the shortages of manpower due to travel ban, shorts seasonal and informal farm laborers. Employment losses around the world have increased rapidly. The ILO valued that COVID-19 has effected 2.7 billion workers $(81 \%)$ of the worldwide labor force due to the partial closure. To defeat all these situations, many governmental and nongovernmental administrations are playing an essential job to sustain a continued food supply chain. Currently, the main goal of the FAO, is to preserve the food value chain and maintain the food supply smoothly.

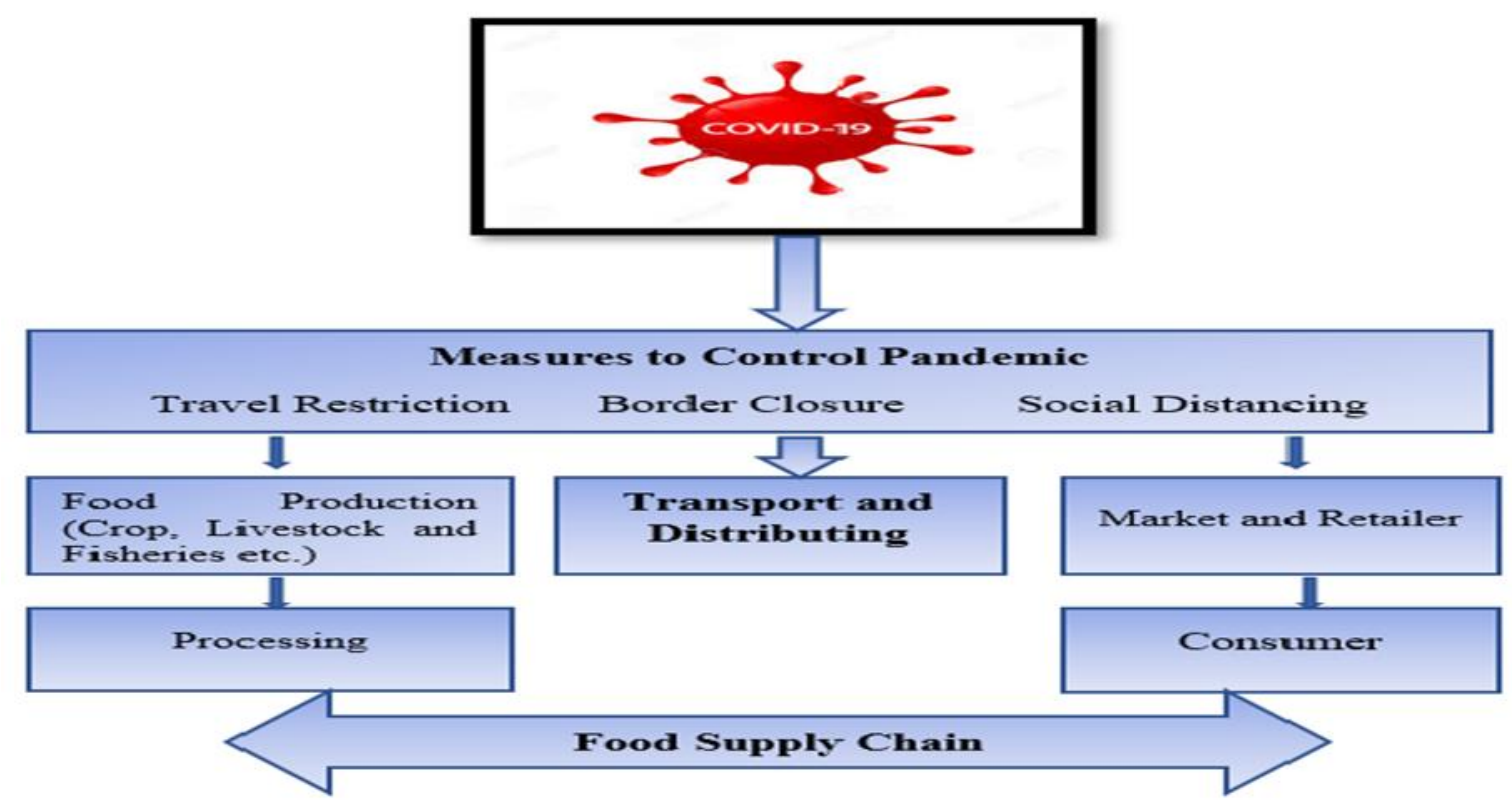

Figure 2. Indicates that COVID-19 effects all stages of the food supply chain and has a significant impact on the transportation and distribution of food

\section{COVID-19 and impacts on food demand and security}

Demand implies to the ambition and ability of consumers to buy commodities and services within a specific time. As income and purchasing power decline, the demand of food is affected. Panicked consumers are storing food, which in turn effects food supply and prices. Moreover, commodity prices depend on the country and its pandemic management and control policies. According to Siche, the costs of fundamental requirements are required to remain constant, while the prices of highvalue products may soar [15]. In the current situation, the consumption of animal proteins has been greatly reduced due to misleading information regarding animals as hosts of viruses.

Food safety and security simply means providing a suitable quantity of nutritious food in a stable way. Because of the reduction in worldwide trade, the production of food and food supply chain are disrupted, and food insecurity may occur. The FAO has revealed that small 
growers and fishermen may encounter problems in marketing their goods, resulting in a decline in their purchasing power and income. The insecurity of food caused by CAVID-19 will seriously disturb the poorest and susceptible part of the world population. Currently, chronic hunger prevails through 820 million people and 113 million people face severe insecurities [19]. Therefore, access to food problems caused by pandemic will immediately and severely effect these masses. About 10 million children rely on school meals to meet up their food needs. Moreover, due to the closure of the school and the postponement of the school meal plan, these children no longer have daily school meals, which may reduce their ability to resist the virus [20].

\section{COVID-19 its impacts on global economy}

Firstly, the market is more integrated and interconnected, and the Chinese economy has contributed $16 \%$ of global gross domestic product (GDP). Therefore, any shock that effects China will currently have a very greater impact on the global market. Secondly, supply shocks due to mortality and disease, as well as containment measures that impede liquidity and business costs due to supply chain constraints and credit crunches will influence the economy, leading to a decline in economic growth. In March 2020, the Organization for Economic Cooperation and Development (OECD) reduced its estimates for world economic growth from $2.9 \%$ to $2.4 \%$, the lowest level since the economic crunched a decade ago and warned that long-term and dense coronavirus pandemics may even make this number halved (only 1.5\%). Thirdly, demand will also decline because of increased insecurity, enhanced preventive behavior, curbing work, and rising financial costs (reduced spending power). Finally, the exchange rate of the US dollar against the US dollar depreciates significantly, which will also effect importdependent counties.
The world food market does not spare these developments. However, they are less effected than other industries, such as travel, manufacturing, and energy markets, which are more vulnerable to logistics disruption and weakened demand (Source: Market Monitor, AMIS, March 2020). Although provided the intricacy of food value chain and the significance of trade and transportation, these may make them very susceptible. Although COVID-19 may signify the deflationary shock of the worldwide economy, which was manifested in the initial actions of the FAO, Food Price Index, in the short term, the actual cost of a healthy diet may rise due to the price expansion of fresh goods. This will have a mostly drastic impacts on low-income households/families and raise the cost of achieving the sustainable developmental targets. As demonstrated in the 2020 state of world food security and nutrition, this impact will be crucial in countries that are highly dependent on commodity imports. Here, the negative impact is even stronger, because every $1 \%$ increase in dependence on commodity imports will cause the number of undernourished people to increase by an average of $3.8 \%$ per year. When the country relies on food imports, undernourishment increases by an average of $8 \%$ per year. In addition, the demand shock will lead to the extension and deterioration of the effects [4].

\section{Conclusion and recommendations}

From all of the above, we assume that the world's food, agricultural sector, markets and economy are not outside the impacts of CAVID-19. Livestock, fisheries and crops are effected by this dangerous pandemic. Under the current circumstances, food security and food safety are serious issues of worldwide concern. The COVID-19 severely impacted the supply chain, which threatened the food safety and security of the most vulnerable people. In addition, most migrants, informal seasonal agricultural workers are being resettled, which may affect the requirement for food. Thus, the government should consider 
controlling epidemics without effecting the food security, safety and supply chain considerations of its citizens. The COVID19 pandemic is a global problem that has effected the food and agricultural sectors. There is need take immediate steps to ensure the vivacity of the food supply chain both internally and externally to reduce the risk of severe shocks that can have a profound impact on all individuals, especially the poor and the most helpless. Although there have been very disturbances to the food supply chain to date, it still faces some strategic challenges. Food needs to cross unlimited boundaries and meet existing food safety standards. To reduce the influence of the pandemic on agriculture and food, the FAO urges countries to meet the existing food requirements of vulnerable public, strengthen their social safety programs, continue global food trade development, continue the implementation of national food supply chain strategies, and support the power of smallholder farmers to increase food production. Countries with humanitarian problems are at higher risk of contracting the COVID-19 epidemic. Although the number of domestic needs may increase due to the epidemic, it is important for donor countries to continuously ensure humanitarian assistance to be provided when food insecurity is already severe. The disease does not recognize the borders of the countries. If left unaddressed, all human society will be in danger.

\section{Author contributions}

Conceived and designed the experiments: $\mathrm{N}$ Khan \& M Ihtisham, Performed the experiments: N Khan, BN Siddiqui \& N Khan, Analyzed the data: N Ullah \& A Wali, Contributed reagents/ materials/ analysis tools: N Khan, S Ismail \& IU Khan, Wrote the paper: N Khan.

\section{Acknowledgments}

I am very grateful to Dr. Muhammad Ihtisham for conceiving the idea of this study, proving technical guidance and English editing support.

\section{References}

1. Bondad-Reantaso MG, Mackinnon B, Bin $\mathrm{H}$, Jie, $\mathrm{H}$, Tang-Nelson $\mathrm{K}$, Surachetpong W \& Karunasagar I (2020). SARS-CoV-2 (The Cause of COVID-19 in Humans) is Not Known to Infect Aquatic Food Animals nor Contaminate Their Products. Asia Fish Sci 33(1): 74-78.

2. Cepal N (2020). Employment Situation in Latin America and the Caribbean. Work in times of pandemic: the challenges of the coronavirus disease (COVID-19). pp. 1-56.

3. FAO (2020). Food systems and COVID-19 in Latin America and the Caribbean: Contingency plan for an eventual food supply crisis. Bulletin 6 . Santiago, FAO. https://doi.org/10.4060/ca9333en

4. Coronavirus O (2020). The World Economy at Risk. OECD Economic Outlook, Interim Report March.

5. D'Agnese ER (2020). A One-Health Perspective on the Effects of Fisheries and Aquaculture on Recovering Fur Seal Populations. University of California, Davis.

6. Do Y, Been HY \& You H (2020). Coronavirus Disease 2019 (COVID19).

7. Emadi MH \& Rahmanian M (2020). Commentary on Challenges to Taking a Food Systems Approach Within the Food and Agriculture Organization (FAO) Food Security and Land Use Change under Conditions of Climatic Variability. Springer (pp. 19-31).

8. Gruszczynski L (2020). The COVID19 Pandemic and International Trade: Temporary Turbulence or Paradigm Shift. European J of Risk Regul 11(2): 337-342.

9. Hanashima M \& Tomobe KI (2012). Urbanization, industrialization, and mortality in modern Japan: a spatiotemporal perspective. Annals of GIS 18(1): 57-70.

10. Holtgrave DR \& Greenwald R (2016). A SWOT Analysis of the updated 
National HIV/AIDS Strategy for the US, 2015-2020. AIDS and Beha 20(1): 1-6.

11. Johnson NP \& Mueller J (2002). Updating the accounts: global mortality of the 1918-1920" Spanish" influenza pandemic. Bull of the His of Medi 76(1): 105-115.

12. Marlow S (2020). COVID-19: Effects on the Fertilizer Industry. IHS Market 24(3): 2-6.

13. Monitor I (2020). COVID-19 and the world of work: Updated estimates and analysis

https://www.ilo.org/wcmsp5/groups/p ublic

14. Perera RA, Mok CK, Tsang OT, Lv H, Ko RL, Wu NC \& Chik TS (2020). Serological assays for severe acute respiratory syndrome coronavirus 2 (SARS-CoV-2), March 2020. Euro 25(16): 2000421.

15. Poudel PB, Poudel MR, Gautam A, Phuyal S, Tiwari CK, Bashyal N \& Bashyal S (2020). COVID-19 and its Global Impact on Food and
Agriculture. J Biol Today's World 9(5): $1-4$.

16. Siche R (2020). What is the impact of COVID-19 disease on agriculture. Sci Agrope 11(1): 3-6.

17. Simonsen L, Reichert TA, Viboud C, Blackwelder WC, Taylor RJ \& Miller MA (2005). Impact of influenza vaccination on seasonal mortality in the US elderly population. Archi of Inter Medi 165(3): 265-272.

18. Singh I (2020). Agriculture in the time of COVID-19. The Hindu, Business Line.

19. Usher K, Durkin J \& Bhullar N (2020). The COVID-19 pandemic and mental health impacts. Inter $J$ of Ment Health Nurs 29(3): 3-15.

20. Zhang $X$ (2020). Chinese livestock farms struggle under COVID-19 restrictions. Research Post of International Food Policy Research Institute. Available in: https://www.ifpri.org/blog/chineselive stock-farms-struggle-under-COVID19 restrictions. 